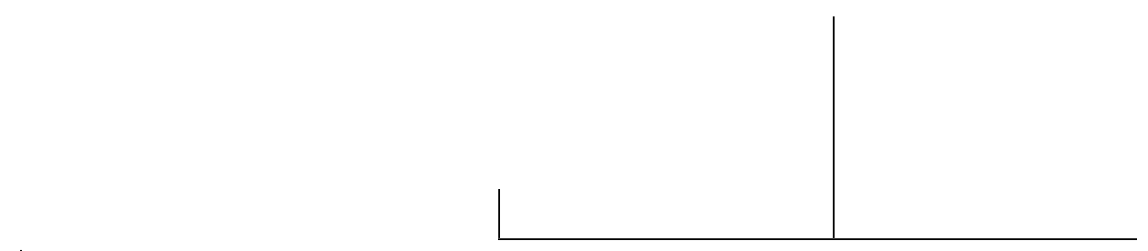

Rev. Latinoam. Psicopat. Fund., São Paulo, v. 15, n. 3, p. 718-731, setembro 2012 (Suplemento)

\title{
Obesity: Listening Beyond the Fat Cells
}

\author{
Junia de Vilhena \\ Joana de Vilhena Novaes \\ Carlos Mendes Rosa
}

What relation does obesity have with mental suffering? The authors investigated the relationship between traumas, melancholia, and loss, and show that obesity represents an attempt to fill in a void that goes beyond food. Based on the recognition of mental suffering, the authors underscore the need for a new type of therapeutic listening that promotes new ways of dealing with the emptiness of one's existence.

Key words: Obesity, trauma, emptiness, psychoanalysis 
Why does someone eat? What makes someone eat so much that, at times, a person can barely walk? Eating until one's life is put at risk, and eating to the point that excess weight will bring serious limitations to quality of life. Why do patients, amid the difficulty to find time for anything, seek clinical psychology services at a public hospital where, initially, they sought care for complaints of physical symptoms caused by their obesity? The aim of the present paper is to investigate the association between obesity and the psychological structure of a person. We investigate the correlation between obesity and psychological suffering. Though the paper focuses on public hospital patients, we do not aim to address the specificities of public or private care.

Non-adherence to the treatment of disorders of orality, using the very appropriate concept put forth by Magtaz (2008), indicates the need to involve patients in their own symptomatology. The numerous cases of unsuccessful bariatric surgeries demonstrate the need for articulating a combination of body and psychological treatments (Rocha et al., 2009). Obesity is a symptom, since it constitutes a structured phenomenon such as a language. However, it is also an enjoyment that was not well managed. It is a symptom that results from jouissance that captures the subject, leaving him or her in suspension. It is less a resistance to contemporary beauty patterns than a state of suffering that enslaves people, as Novaes $(2006,2010,2011)$ has suggested several times. In this sense, Vale Rosa \& Campos (2009) underscored that obesity is not necessarily a somatization, a psychosomatic disorder, or a disease; it is a complex and unique disposition of the subject to become human. It is marked by its dependence on the psychological structure of a person.

\section{Are you fat only if you want to be?}

Clinical practice of individuals with metabolic syndrome involves patients who present with multiple complaints, in addition to numerous psychosomatic diseases, such as: fibromyalgia, gastritis, and skin 


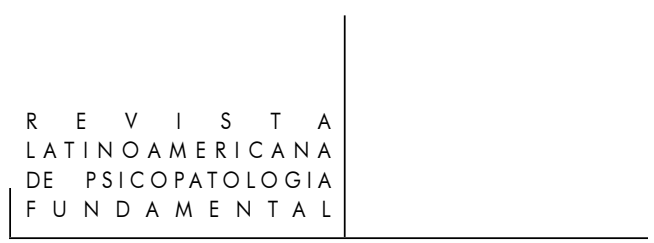

diseases. One of the recurring symptoms, or responses, to binge eating is depression.

Prejudice against obesity is one of the most socially validated types of discrimination. Even among medical doctors there is anecdotal compassion toward anorexic patients and, more often than not, an aversion to obese patients. Obesity is often associated with moral weakness and lack of willpower, and even with shamelessness (Novaes, 2011).

Clinicians commonly report obese patients' lack of commitment. Lack of commitment is sometimes understood as a conscious refusal to adhere to a clinical program. Lack of willpower, tenacity, and determination is reported. This shows, unequivocally, the presence of the intimate association between body fat and derogatory moral judgment in our social imaginary.

Similarly, it seems that clinicians simply accept the fact that obese patients, faced with their depressed mood, give in to binge eating. This reveals both resistance to treatment and a defense mechanism to anesthetize the patient's pain. Lack of control and autonomy in relation to one's own body may easily arouse a strong feeling of frustration in the healthcare professionals involved.

The questions addressed here are: what should be done with patients who are diagnosed with hyperphagia, who normally report several dramatic events when asked about one specific episode that would justify a change in their eating habits? How can we avoid a prejudiced view that accuses the patient of failure if the expected weight loss goals are not achieved? How can we move the patient away from the idea of someone who is sick to someone who is receiving care?

Frequently, what is observed is that there is total detachment between patient and symptom. The body is treated only as a living organism; the body is part of nature, it is something that medicine will take care of masterfully. There is an imposed silence on the deepest meanings of body organs: as if patients were living in bodies without any narrative. As Birman (2003, p. 10) states, the patient's subjectivity was progressively excluded and silenced from the sphere of the infirmity; it was excluded from carrying any implication in relation to the process of getting sick.

To be sure, there is a difference between the representation of the body and the instinctual body, the real body which is situated beyond the representational body. The instinctual body - as a category - distinguishes itself from the symbolic and from the biological bodies without, however, excluding them. Therefore, we understand that the study of body transformations cannot be decoupled from the narratives associated with the bodies. Medical doctors, in their relation with the body, have the attitude of a man taking apart a machine (Lacan 1985, p. 97).

The body investigated by psychoanalysis is very distinct from the body investigated by medicine: it is not merely a living organism, a collection of flesh 


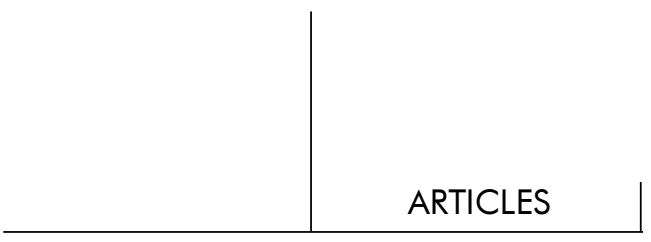

and organs; it is a body that speaks, enjoys, silences, and becomes deaf, always waiting to be deciphered. It is in this context that medicine is called upon to cure obesity as a disease. It is also in this context that obesity seems to have no psychological causes stemming from the unconscious (Vilhena \& Novaes 2009).

The issue is therefore to articulate each one of the affections or symptoms in association with the discourse produced by the body. It is in the search for meaning and for a narrative for the different subjective experiences that the subject will no longer be a stranger in his or her own body. In other words, we are trying to highlight the gap between the medical and the psychoanalytical views of the same patient: a clinician may see a patient that lies, whereas a psychiatrist may see a patient who is delirious, and a psychoanalyst may try to understand what the body is trying to say.

\section{Traumas and losses}

Since its early days, research in psychoanalysis has focused on the issue of psychic traumas at the source of neuroses. In the paragraphs below, we present a brief discussion of Freudian approach to trauma, from 1895 to 1926.

According to Rudge (2009), the theory of seduction (Neurotica) presents a model that can be divided into two periods: excessive excitement experienced early and which is not relieved is later associated with an event, which is called aprèscoup; in other words, belated attribution of unbearable memories which will become, therefore, repressed. With the development of infant sexuality theory, and of metapsychology, traumatic events become connected to original ghosts and the afferent repressed anxiety (seduction, castration, primal scene, Oedipus complex). In this sense, trauma is associated with the strength of sexual drive on the psychological structure of the individual and, consequently, on conflicts and traumas associated with ghosts of the unconscious and psychic reality.

Also based on Rudge's work only after 1920 the concept of trauma acquires a more significant dimension. At that point in Freud's work, the concept becomes a breach (effraction) in excitement, in a situation in which the ego is aggressively confronted with a reality to which it cannot attribute qualities, to which it cannot attribute meaning. In other words, the psyche receives excessive influx of detached excitations without representation. In the Freudian theory, the characteristic excess of trauma (of the traumatic) is always sexual in nature; and abandonment is the prototypical traumatic situation. Abandonment is associated with the fact that the infant is totally dependent on the care of others (who provide sexual stimulation and initiate instinctual life) since the infant is incapable

Rev. Latinoam. Psicopat. Fund., São Paulo, v. 15, n. 3, p. 718-731, setembro 2012 (Suppl.) 


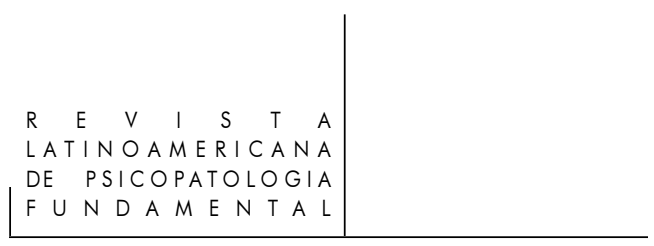

of appeasing internal functions. In 1926 a new theory of anxiety is put forth, with traumatic experiences being connected to the loss of an object (Bokanowski, 2002).

For Ferenczi, trauma is associated with commotion, a reaction to endogenous or exogenous excitation which modifies the Self (autoplastic). However, trauma is something that changes excitation (alloplastic). This new composition of the Self is unviable unless there is a previous, partial or total destruction of the preceding Self. According to Bokanowski (2002), Ferenczi established metapsychological grounds for traumas different from those theorized by Freud in 1926. Ferenczi's traumas were not associated with seduction; rather, they could originate in excessive or missing maternal care or, still, in the absence of object. For Ferenczi (1934) it is a matter of violation of thought and affection: be it by way of disqualification or by way of denying the affection any recognition.

In this approach, early traumas are placed among negative experiences with the other; they are connected with several non-responses of the environment to the affective needs of the subject. These situations make subjects experience the asphyxiation of their psychic lives, a type of paralysis of thought and of the ego that, consequently, are secondary to open wounds. The result of this process is an egoic rupture (cleavage), which, once established, will brutally change the relationship with the object. If the relationship with the object becomes impossible, then it becomes a narcissistic relationship.

In this case, the "invalid unconscious" is associated with the existence of affective states that are not integrated by subjectivity. There are excessively intense affective experiences that could not be included into a chain of representations. They never evoked a response from the surroundings that was capable of symbolically comforting and articulating this type of intensity.

According to Winnicott (1963) emptiness is the basis for the act of eating and for learning; it is a prerequisite for wanting something inside of oneself. The problem is that emptiness may take hold during a stage in the subject's life in which he or she is not mature enough to assign meaning to it. Therefore, the subject fears the horror of emptiness and tries to defend him or herself from it at any cost, by organizing a controlled emptiness (not eating) or binge eating in an unforgiving and compulsive manner.

The ego organizes defenses against the collapse of the organization of the ego itself. The ego is always the structure being threatened. Winnicott (1963) advocates that this type of defense is established against a specific type of primal, underlying agony. Hence, the fear of collapse described by the author is the fear of a collapse that has already been experienced in some earlier stage of the 
development of the subject (p. 72); it was not taken in by the integration of the ego in a satisfactory manner.

The right amount of solitude can be beneficial. However, as Magatz stated, if the duration of one's loneliness is prolonged, it begins to become bothersome; it places the subject face to face with him or herself, with nothing to do. Prolonged solitude leaves the subject with a feeling of morbidity, of uselessness, of insignificance. One is left alone with one's own soul, one's own thoughts, demanding a reason for one's existence. One's thoughts are constant reminders of the feeling of a recent loss of someone dear, of a loss of a job, of a sudden change in the way of life, of the end of a cycle, of an inevitable fatality. But what to do when one seeks to anesthetize the pain by eating ravenously and maniacally?

Repetitive behaviors allow for the relief of unbearable excitation: the feeling of being absolutely full, binge eating, and the act of vomiting (or even intense exercise) allow for an emptiness of thought (Magtaz, 2008).

The search for the feeling of being full, or empty, replaces the unbearable feelings of loss. The alternative to dependence, and the possible detachment from the object, is the unleashing of compulsive behavior through which the subject tries to control the object. The subject will eat more and more, and feel fuller and fuller, though never full enough and then eat again; the subject will seek filling all the empty voids, without fail. The subject may fear the hiatuses that are evidence of our damnation for being beings that speak. Obese subjects are devoured by their own jouissance (Rocha et al., 2009).

Patients incapable of losing weight or that show little progress, after numerous unproductive attempts of trying miraculous diets, resort back to their maniacal rituals of eating. These rituals are followed by feelings of numbness that invade their souls making patients feel trapped in their own bodies and incapable of breaking with the tautological cycle of eating, anesthetizing, and guilt.

Freud (1926) postulated the existence of a more primal tendency, even more primal than the psyche, which is the compulsion to repetition; this precedes the principle of pleasure, and its aim in life is to return to an inanimate stage, which precedes life and stems from external perturbations. The compulsion to repetition and suicidal tendencies, which are characteristic of melancholia, the lack of desire, the poverty of fantasies, and the emptiness, the repetitive and empty speech are some of the manifestations of a strong presence of death drive in the psychic life of these subjects.

Depression results in a perturbation of the libido, in the incapacity to love. For Abraham (1924), the impotence associated with depression stems from a stance of hatred, of intense anger. This anger is projected to the outside, and depressed subjects consequently do not feel loved; they will maintain that the world 


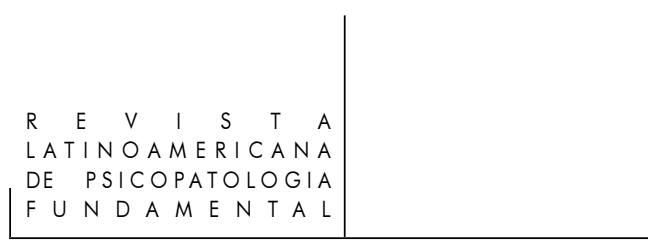

does not give them love because of their unbearable flaws, hence their deep state of unhappiness. Sadistic impulses are very much present and are revealed in Freudian slips, in dreams, and also, more clearly, in the desire for revenge and hostile attitudes toward people and things. There is also melancholia, the primitive stage of the anal-sadistic phase in which the patient abandons psychosexual reactions to the object, destroys it and expels it. This relationship is similar to that between the obese and their objects of ingestion.

Since his early writings, Freud advocated the direct relationship between melancholia and disorders of orality. Freud's description of the personality of melancholic patients (1917) takes the reader to the sessions with a young woman whose eight-month treatment could be summed up as persistent weeping. This, in turn, signaled in the direction of a poorly resolved mourning of a grandmother she lost ten years earlier. The weeping, however, was fundamental for the recognition of her pain, and for the development of the sadness that will precede health. Paradoxically, the weeping frees the patient from a stagnant emotional stage that is held in place through mania (in this case, the frequent episodes of binge eating).

Another way of understanding melancholia is that it is the result of a shadow of an Ideal Self. This Ideal Self is overvalued in one's imagination and turns itself against the subjects, who are defenseless in their psychological structure. The question that arises is how would it be to elaborate the emptiness that results from the shadow of the ideal body? The ideal body is created by collective imagination and internalized by contemporary women as a natural law of life rather than something they choose to pursue. On the one hand, anorexia and bulimia are the incessant and pathological search for the ideal body; on the other, obesity may be a declared relinquishment of this search, such as the melancholic patient who relinquishes the search for the Ideal Self.

In this same vein, the works of Abraham (1916 and 1924) present crucial contributions for the clinical understanding of disorders of orality. The author presented pieces of several clinical cases showing that the instinctual life of the infant may persist in the adult stage, and that the libido of such persons presents a picture associated with psychopathological disorders that seem to be associated with the oral stage. They were cases of psychic stages of depression, according to the author, several neurotics suffered from abnormal feeling of hunger and the symptom affected women in particular (Abraham, [1916]1970, p. 64).

This type of neurotic hunger, which is different from normal hunger, has particular characteristics. Patients generally complained of crises of ravenous hunger. Patients were also resistant when psychoanalysis indicated an association between ravenous and neurotic hunger and repressed libido. Abraham underscores the incidence of crises of ravenous hunger in frigid women.

Rev. Latinoam. Psicopat. Fund., São Paulo, v. 15, n. 3, p. 718-731, setembro 2012 (Suppl.) 
Abraham also reminds us that repressed libidinal impulses may be masked by a feeling of hunger. Hunger, even if excessive, may be socially admitted to oneself and to others. He writes about the problem of neurotic depression of spirits and suggests that autoerotic satisfaction of the neurotic person may serve two purposes: stopping the onset of a dangerous depression of spirits or even overcoming depression.

Abraham's observations are congruent with the aptitude for movement observed by Lasègue (1998) in hysterical patients. There is pleasure and a feeling of well-being - as illusions of narcissistic gratification - that placate anguish and sadness. There is also a gradation in the aptitude for movement, ranging from something rhythmic and continuous (as a lullaby) to rapid and frantic movements, as a maniacal action that hinders rational thought (for example, walking excessively and nonstop, eating to vomit).

According to Abraham and Torok (1995) among the most important manifestations of depressive mental disorders there are two symptoms that have a direct relation with the oral stage: the refusal to eat and the fear of starving to death. Here, eating replaces loving; the melancholic patient loses the ability to love while fearing death from love. This reveals what the author named the nature of the forces responsible for the stagnation that is characteristic of melancholia.

In this sense, it is important to remember that the layers of fat carried by the obese patient represent, unsuspectingly, the protection and shield against the dangers of emotional ties (Novaes, in press). The understanding of this neurotic manifestation led Abraham to the conclusion that in obese patients libido had regressed to a more primitive stage of development, the oral phase (Abraham, [1916]2000).

The more genitals are replaced as the source of pleasure, the more people turn to oral and anal eroticism. In melancholic depression, libido regresses to its most primitive stage of development. Unconsciously, the melancholic patient will desire to incorporate his or her object of desire. Devour it to destroy it (Berlinck, 2009).

Denial allows for a double negative. Ultimately, that means an affirmative; in other words, the individual is aware of the fact but will do everything to deny it. Consequently, the act of denial or defense needs to be relived again and again, so much so that the denied psychic component will neither cease to exist nor be accepted. The compulsive acts of destruction of food may be associated in this same logic of denial of reality. 


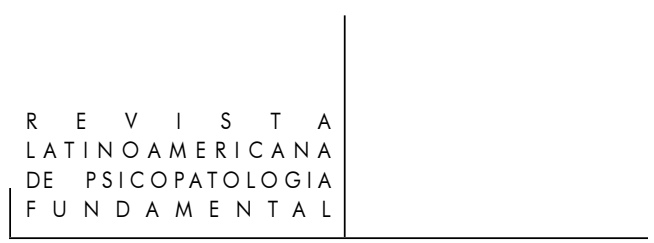

\section{Careful listening}

The issue may be thus articulated: how to conceive of a clinical field which investigates a superposition of symbolic (discourse, social, political, and cultural), psychic, and physical (somatic and environmental) objects? Based on the concept of recognizing pain, which is here understood as sadness which needs to be shared so the patients can legitimize the place of their suffering, we introduce a fundamental concept to rethink the function of therapeutic listening: the notion of care as something that promotes and allows for the subject to find the path toward being healthier.

The taxonomy of the concept of recognition proposed by Honneth (2003) establishes that it is within the realm of love and care that our practice and the management of clinical trauma with obese patients are situated. It is especially difficult to come across the realms of right and solidarity within the space of individual care. This is due to the individualizing and naturalizing trend that characterizes most practices of individual care.

In the realm of love, it is relevant to underscore the importance of caretakers' comforting and lucid support; they will allow others to build selfconfidence and critically appropriate their identity possessions. Building selfconfidence and identity will help the individual creatively establish alternatives for coping with pain, identifying vulnerabilities, and overcoming obstacles to one's projects for life and happiness.

This is the realm in which, based on a singular and unfathomable nucleus of individuality delimitations and "unlimitations" of personal identity are established by means of exchanges of affection with those who are responsible for one's care. Honneth, agreeing with Winnicott, establishes that it is based on the relationship with the mother (or the person playing the role of the mother) - based on the way this person establishes her place in the world (based on her own presence) - that the processes of delimitations of identity of the Self (and the other) are formed.

However, the movement toward delimitation is inseparable from a movement in the opposite direction. A movement in which the Self will seek to "unlimit" itself .The Self will break these limits in the incessant search for ways in which it may be affected by the external world in increasingly richer ways, throughout its physical, psychic, and social development. Primarily, it is with the mother figure that the subject establishes emotional contact. But the subject will also progressively establish contact with others who accept his or her "unlimiting" impulses and, at the same time, establish new limits (the good-enough mother). The mother figure and the other give the individual the security and selfconfidence that is needed for individuation and socialization.

Rev. Latinoam. Psicopat. Fund., São Paulo, v. 15, n. 3, p. 718-731, setembro 2012 (Suppl.) 
Magtaz states that enactment seems to dominate the treatment of patients with disorders of orality. Patients' talks are almost exclusively about their bodies, fat, foods, and diets. There is an observable inability to retain satisfactory experiences from the weekly meetings; there is also an inability to assimilate the security of the continuous and constant characteristic of the meetings. Patients need constant reassurance that they will not be abandoned and will not lose the love, care, and attention from the analyst (Novaes, in press). This need represents the inability to symbolize the affection, in other words, the inability of the patient to build an abstract representation about the presence of the other.

It is important not to forget that these patients' feelings are a result of their projection of their failure in the daily struggle against their compulsion. Therefore, we must be prepared to not let the projection be incorporated, rather, that it be elaborated and returned to the patient. Otherwise, we will merely reproduce the same affective ambivalence, in countertransference (Radó, 1927).

According to Magtaz, the constant discourse of diets, of weight loss, and of the body serves as identity marks for these subjects. Our point is that by carefully listening to these patients we favor new forms of visibility and identity.

In the poem "Retrato" (Portrait), Meirelles (1994) asks: in which mirror did I lose my face? Existing is, above all, presenting one's image to another. When something is not seen, it does not exist - to be is to be perceived. But being is, first and foremost, being something to someone.

Seeing and being seen are two sides of the same coin in human relations. In this case, it is possible to add that seeing is also being perceived differently; being something else to ourselves (Vilhena et al., 2011). Patients are nothing if they cannot rely on the comforting perspective of the other, if they are not seen beyond the failure of numerous diets. Otherwise, they will be merely an amorphous mass of fat cells.

Bibliography

Aвraham, K. (1916). O primeiro estágio pré-genital da libido. In: Teoria Psicanalítica da libido. Rio de Janeiro: Imago, 1970. p. 51-80.

Abraham, K. (1924). Breve estudo do desenvolvimento da libido visto à luz das perturbações mentais. In:Teoria Psicanalítica da libido. Rio de Janeiro: Imago, 1970. p. 81-160.

Abraham, N.; Torok, M. A casca e o núcleo. São Paulo: Escuta, 1995.

BerLInCK, M. T. As bases do amor materno, fundamento da melancolia. In: $6^{\circ}$ Congresso Norte Nordeste de Psicologia. Belém, Pará, 2009.

Rev. Latinoam. Psicopat. Fund., São Paulo, v. 15, n. 3, p. 718-731, setembro 2012 (Suppl.) 


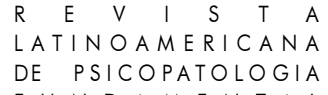

Birman, J. Mal-estar na atualidade. A psicanálise e as novas formas de subjetivação. Rio de Janeiro: Civilização Brasileira, 2003.

BокаNowsкi, T. Traumatisme, traumatique, trauma : Le conflit Freud/Ferenczi. Revue française de psychanalyse, N. 66, p. 745-757, 2002.

Ferenczi, S. (1934). Réflexions sur le traumatisme. Trad. Équipe du Coq Héron. In: OEuvres complètes IV. Paris: Payot, 1982. p. 139-147.

FReUd, S. (1917). Luto e melancolia. In: Edição Standard Brasileira das Obras Psicológicas Completas de Sigmund Freud. Rio de Janeiro: Imago, 2006. V. XIV.

Freud, S. (1926). Inibição, sintoma e angústia. In: Edição Standard Brasileira das Obras Psicológicas Completas de Sigmund Freud. Rio de Janeiro: Imago, 2006. V. XX.

HonNeth, A. Luta por reconhecimento: a gramática moral dos conflitos sociais. São Paulo: Ed. 34, 2003.

LaCAN, J. O Seminário. Livro 2. O eu na teoria de Freud e na técnica da psicanálise. Rio de Janeiro: Jorge Zahar, 1985.

Lasègue, C. (1873). Da anorexia histérica. Revista Lat. de Psic. Fundamental, São Paulo, v. I, n. 3, p. 158-171, out. 1998.

Magtaz, A. C. Distúrbios da oralidade na melancolia. 2008. 191 p. Tese (doutorado em Psicologia Clínica). Pontifícia Universidade Católica de São Paulo, 2008.

Meireles, C. Poesia Completa. Rio de Janeiro: Nova Aguilar, 1994.

Novaes, J. de V. Beleza e feiúra. Sociabilidade e usos do corpo em mulheres das camadas altas e populares da zona sul carioca. In: Del Priore, M. (Org.). A história do Corpo no Brasil. São Paulo: Ed. Unesp, 2011. p. 477-506.

Novaes, J. de V. Você tem fome de quê? Sobre a clínica de obesidade em um hospital público. In: Vilhena, Junia; Novaes, Joana V. (Orgs.). Corpo para que te quero? Ensaios sobre o corpo na cenacontemporânea. Rio de Janeiro: Ed. PUC (prelo).

Novaes, J. de V. Com que corpo eu vou? Sociabilidade e usos do corpo nas mulheres das camadas altas e populares. Rio de Janeiro: Ed. PUC/Pallas, 2010.

Novaes, J. de V. O intolerável peso da feiúra. Sobre as mulheres e seus corpos. Rio de Janeiro: Ed.PUC/Garamond, 2006.

RADÓ, S. El problema de la melancolia. In: Garma, A.; Rascovsky, L. (Orgs.) Psicoanálisis de la melancolia. Buenos Aires: El Ateneo, 1948. p. 251-270.

Rocha, L. et. al. Sobre a obesidade mórbida: de que trata este comer? Psicologia em Revista, Belo Horizonte, n. 2, v. 15, p. 77-96, 2009.

Rudge, A. M. Trauma. Psicanálise passo-a-passo. Rio de Janeiro: Zahar, 2009.

Vale Rosa, T.; Campos, D. Aspectos psicodinâmicos em sujeitos que fizeram a 


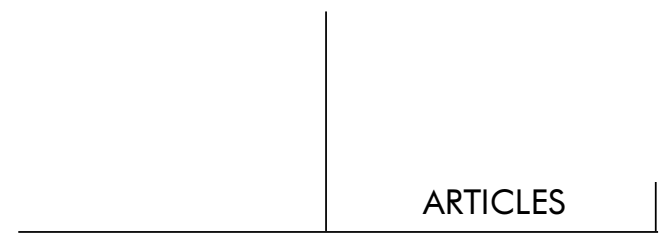

cirurgia bariátrica sem indicação médica. Rev. Mal-estar e Subjetividade, São Paulo, v. IX, n. 1, p. 105-133, 2009.

VilhenA, J. et. al. À la recherche d'une écoute.La clinique psychanalytique dans la banlieue de la citoyenneté. Revista Lat. Psic. Fundamental, São Paulo, v. 14, n. 2. p. 283-297, jun. 2011.

Vilhena, J.; Novaes, J. de V. Un corps à la recherche d'un logement. Corps, violence et médecin. In: Masson, C.; Desprat-Pequignot, C (Orgs.). Le corps contemporain: créations et faits de culture. Paris: L'Harmatan, 2010. p. 113-136.

Winnicott, D. (1963). O medo do colapso. In: Winnicott, C. (Org.). Explorações psicanalíticas. Porto Alegre: Artmed, 1994. p. 70-76.

\section{Abstracts}

(Obesidade: uma escuta para além das células adiposas)

Qual a relação entre a obesidade e o sofrimento psíquico? Investigando a relação entre trauma, melancolia e perda os autores apontam como a obesidade busca preencher uma falta que não é puramente da ordem do alimento. Calcados no reconhecimento da dor, apontam a necessidade de uma nova escuta terapêtica que promova a possibilidade de uma outra forma do sujeito lidar com o vazio de sua existência.

Palabras-chave: Obesidade, trauma, vazio, psicanálise

(Obésité: à la recherche d'une écoute au delà des cellules adipeuses)

Quel est le rapport entre l'obésité et la souffrance psychique? Lors d'une enquête sur le rapport entre les traumatismes, la mélancolie et la perte, les auteurs décrivent de quelle façon l'obésité cherche à combler un manque qui n'est pas uniquement d'ordre alimentaire. Partant de la reconnaissance de la douleur, les auteurs défendent la nécessité d'une nouvelle forme d'écoute thérapeutique des patients dans le but de favoriser une autre forme de soutien à la vacuité de leur existence.

Mots clés: Obésité, traumatisme, vacuité, psychanalyse

(Obesidad: escuchar más allá de las células adiposas)

¿Cuál es la relación entre la obesidad y el sufrimiento psíquico? Al investigar la relación entre el trauma, la melancolía y la pérdida, los autores señalan cómo la obesidad trata de rellenar un vacío que no es puramente del orden alimentar. Basados en el reconocimiento del dolor, apuntan para la necesidad de una nueva escucha terapéutica que posibilite al individuo lidiar de una otra forma con su vacío existencial.

Palabras claves: Obesidad, trauma,vacío, psicoanálisis

Rev. Latinoam. Psicopat. Fund., São Paulo, v. 15, n. 3, p. 718-731, setembro 2012 (Suppl.) 
(Übergewicht: ein Hinhören jenseits der Fettzellen)

Welchen Zusammenhang gibt es zwischen Übergewicht und psychischem Leiden? In Ihrer Untersuchung der Zusammenhänge zwischen Trauma, Melancholie und Verlust zeigen die Autoren inwiefern Übergewicht der Versuch ist, einen Mangel zu ersetzen, der nicht reines Ernährungsbedürfnis ist. Aufgrund der Erkennung des Leidens, weisen sie auf die Notwendigkeit eines neuen therapeutischen Hörens, das dem Subjekt eine neue Umgangsform mit der Leere seiner Existenz ermöglicht.

Schlüsselwörter: Übergewicht, Trauma, Leere, Psychoanalyse

Citation/Citação: Vilhena, J. de; Novaes, J.V.; Rosa, C.M. Obsesity: Listening Beyond the Fat Cells. Revista Latinoamericana de Psicopatologia Fundamental, São Paulo, v. 15, n. 3, p. 718-731, sept.2012 (Suppl.).

Editor/Editor do artigo: Prof. Dr. Manoel Tosta Berlinck

Received/Recebido: 18.6.2012 / 6.18.2012 Accepted/Aceito: 20.7.2012 / 7.20.2012

Copyright: () 2009 University Association for Research in Fundamental Psychopathology / Associação Universitária de Pesquisa em Psicopatologia Fundamental. This is an open-access article, which permits unrestricted use, distribution, and reproduction in any medium, provided the original author and source are credited. / Este é um artigo de livre acesso, que permite uso irrestrito, distribuição e reprodução em qualquer meio, desde que o autor e a fonte sejam citados.

Funding/Financiamento: The authors have no support or funding to report. / Os autores declaram não ter sido financiados ou apoiados.

Conflict of interest/Conflito de interesses: The authors declare that has no conflict of interest. / Os autores declaram que não há conflito de interesses.

Rev. Latinoam. Psicopat. Fund., São Paulo, v. 15, n. 3, p. 718-731, setembro 2012 (Suppl.) 


\section{Junia de ViLhena}

Psicanalista; Dra em Psicologia Clínica; Professora do Programa de Pós-Graduação em Psicologia Clínica da Pontifícia Universidade Católica do Rio de Janeiro - PUC-Rio (Rio de Janeiro, RJ, Br); Coordenadora do Laboratório Interdisciplinar de Pesquisa e Intervenção Social - LIPIS da PUC-Rio; Membro do GT da ANPEPP "Processos de subjetivação, Clinica Ampliada e Sofrimento Psíquico; Pesquisadora da Associação Universitária de Pesquisa em Psicopatologia Fundamental (São Paulo, SP, Br); Pesquisadora correspondente do Centre de Recherches Psychanalyse et Médecine, CRPM-Pandora - Université DenisDiderot Paris VII (Paris, France).

Av. Ataulfo de Paiva 135 sala 613 - Leblon

22440-901 Rio de Janeiro, RJ, Br

Fone: (21) 2512-8222 / (21) 99478-2670

e-mail: vilhena@puc-rio.br / lipis@puc-rio.br

www.juniadevilhena.com.br

\section{Johna de Vilhena Novaes}

Psicanalista; Pós-doutoranda em Clínica Médica na Universidade do Estado do Rio de Janeiro - UERJ (Rio de Janeiro, RJ, Br); Pós-Doutora em Psicologia Social pela UERJ; Doutora em Psicologia Clínica pela Pontifícia Universidade Católica do Rio de Janeiro PUC-Rio (Rio de Janeiro, RJ, Br); Pesquisadora do Laboratório de Pesquisas Clínica e Experimental em Biologia Vascular (Bio-Vasc) da UERJ; Coordenadora do Núcleo de Doenças da Beleza da PUC-Rio; Pesquisadora e psicoterapeuta do LIPIS - Laboratório Interdisciplinar de Pesquisa e Intervenção Social (Rio de Janeiro, RJ, Br); Pesquisadora correspondente do Centre de Recherches Psychanalyse et Médecine - Université DenisDiderot Paris 7 CRPM-Pandora (Paris, France); Bolsista da Fundação de Amnparo a Pesquisa do Estado do Rio de Janeiro - FAPERJ (Rio de Janeiro, RJ, Br).

Av. Ataulfo de Paiva 135 sala 613 - Leblon

22440-901 Rio de Janeiro, RJ, Br

Fone: (21) 2512-8222 / (21) 9493-8223

e-mail:joanavnovaes@gmail.com

www.joanadevilhenanovaes.com.br

\section{Carlos Mendes Rosa}

Psicólogo, com especialização em Psicopatologia Clínica pela UNIP - Universidade Paulista (Rio de Janeiro, RJ, Br); Mestrando do Programa de Pós-Graduação em Psicologia Clínica da Pontifícia Universidade Católica do Rio de Janeiro - PUC-Rio (Rio de Janeiro, RJ, Br); Pesquisador Associado do Laboratório Interdisciplinar de Pesquisa e Intervenção Social LIPIS da PUC-Rio (Rio de Janeiro, RJ, Br); Bolsista do Conselho Nacional de Desenvolvimento Científico e Tecnológico - CNPq.

Rua Riachuelo, 257/421 - Lapa

20230-011 Rio de Janeiro, RJ, Br

e-mail: carlosmendesrosa@gmail.com 